\title{
PELATIHAN PEMBUATAN KARYA ILMIAH DIGITAL BAGI GURU- GURU PEREMPUAN SMK NEGERI 4 SURAKARTA GUNA MENGHADAPI REVOLUSI INDUSTRI 4.0
}

\author{
SETYASIH HARINI \\ GANJAR WIDHIYOGA
}

\begin{abstract}
Abstrak
Seorang guru profesional saat ini tidak hanya ditentukan oleh tingginya pencapaian secara akademik namun juga kemampuan dalam membuat kreatifitas dan karya inovasi yang mendukung proses pembelajaran. Permasalahan yang dihadapi oleh guru yang ada di SMK Negeri 4 Surakarta terutama yang perempuan adalah: (1) kurangnya wawasan dari guru-guru perempuan mengenai pentingnya penyusunan publikasi ilmiah sebagai prasyarat untuk meningkatkan kepangkatan (jabatan fungsional); (2) kurangnya kemampuan beberapa guru perempuan dalam penyusunan karya ilmiah; (3) guru masih lemah dalam menyusun artikel ilmiah populer yang dapat dipublikasikan melalui media massa cetak ataupun online. Target dari pelaksanaan Pengabdian Pada Masyarakarat ini adalah sebagai berikut: (1) Melakukan sosialisasi tentang karya ilmiah berdasarkan pada riset yang diwujudkan melalui Penelitian Tindakan Kelas (PTK); (2) Melakukan sosialisasi tentang jurnal sebagai bentuk publikasi ilmiah yang bisa digunakan sebagai sarana untuk meningkatkan profesionalisme; (3) Peningkatan motivasi dalam membuat karya inovasi dan kreativitas guna memperbaiki proses pembelajaran agar lebih menarik bagi para siswa; (4) Meningkatkan kemampuan para guru melalui pelatihan publikasi ilmiah; (5) Memberikan pelatihan penyusunan opini berdasarkan artikel ilmiah untuk diunggah ke media massa online. Luaran yang dapat diberikan melalui pengabdian pada masyarakat ini adalah sebagai berikut: (1) pembuatan laporan hasil pengabdian; (2) pembuatan artikel untuk publikasi ilmiah yang dimasukkan ke dalam jurnal hasil pengabdian; (3) memasukkan artikel dalam bentuk opini ke media massa online. Metode pelaksanaannya adalah melalui sosialisasi, pelatihan, pendampingan dan motivasi. Hasil pelaksanaan kegiatan menunjukkan antusias dan minat besar dari para guru perempuan terhadap sosialisasi dan pelatihan penyusunan publikasi ilmiah yang bersumber dari riset termasuk artikel yang dihasilkan untuk dimuat di media massa cetak dan online.
\end{abstract}

Kata kunci: guru, profesional, pembangunan, publikasi ilmiah

\section{PENDAHULUAN}

Untuk menunjang kegiatan guru dalam melaksanakan tugas pokoknya, seorang guru harus memiliki kualifikasi akademik, kompetensi, sertfikat pendidik, sehat jasmani dan rohani, serta memiliki kemampuan untuk mewujudkan tujuan 
pendidikan nasional. Demikian aturan yang tertuang dalam Perundang-Undangan No. 14 Tahun 2005 tentang Sertifikasi Guru. Melalui legalitas tersebut, guru era milenial tidak hanya dituntut mampu berbagi ilmu pengetahuan dan pengalamannya kepada para peserta didik. Kemampuan akademik yang telah diterima oleh seorang guru melalui pendidikan tinggi dan gelar kesarjanaanya hanya merupakan salah satu unsur pendukung. Kesehatan jasmani dan rohani juga merupakan unsur pendukung karena seorang guru sebagai fasilitator dan motivator di dalam kelas dan sebagai aktor untuk menyelesaikan permasalahan yang dihadapi oleh para peserta didik membutuhkan kehadiran guru yang sehat fisik dan mentalnya.

Keberpihakan pemerintah terhadap dunia pendidikan khususnya kesejahteraan bagi para guru telah dimulai sejak 30 Desember 2005 dengan dikeluarkannya Undang-Undang Sertifikasi Guru. Pengalaman dan sejarah sebelum dikeluarkannya perundangan tersebut, nasib guru dapat diibaratkan seperti pepatah sudah jatuh, tertimpa tangga, kurang menguntungkan. Julukan guru sebagai “Oemar Bakrie” begitu kental terdengar di masyarakat mengingat kesejahteraannya yang kurang mendapat perhatian dari pemerintah. Pelayanan, pengorbanan dan perjuangan para guru tidak sepadan dengan imbalan yang didapatkannya. Kondisi seperti ini lebih terasa bagi para guru yang mendapat tugas di daerah pedesaan yang membutuhkan lebih banyak pengorbanan guna ikut serta mencerdaskan anak bangsa.

Sekilas perlu diingat gagasan dari Boateng (2016) yang menyatakan bahwa globalisasi lebih dimaknai sebagai sebuah masa yang menunjukkan pertumbuhan mobilitas internasional dari berbagai produk, jasa, modal, fasilitas maupun manusia. Tingginya mobilitas tersebut didukung oleh praktik liberalisme dan privatisasi yang di dalamnya diwarnai dengan tingginya kompetisi. Kompetisi diantara para pelaku bukan hanya sebatas terhadap kepemilikan sumber daya, kekuasaan, pasar namun juga kompetisi jasa (pelayanan). Sementara, jika dilihat pada pelaksanaan pendidikan yang berlaku di Indonesia banyak fakta yang menunjukkan adanya pola memanusiakan manusia melalui ranah pendidikan masih menggunakan cara-cara konvensional. Rusniati (2015) justru melihat 
bahwa pelaksanaan pendidikan Indonesia ketika masuk dalam era globalisasi masih diwarnai dengan pengembangan kecerdasan secara sempit sehingga kurang memberikan kesempatan bagi peserta didik untuk meningkatkan kreativitas dan inovasinya. Dalam situasi semacam ini, guru masih menduduki posisi sebagai yang utama dan terutama terhadap pengembangan belajar mengajar siswa.

Gambaran tersebut juga dialami oleh para guru perempuan dari Sekolah Menengah Kejuruan (SMK) Negeri 4 Surakarta. Dalam tahun ajaran 2018/2019 ini, SMK Negeri 4 Surakarta telah memiliki guru sejumlah 81 orang. Untuk peserta didik laki-laki berjumlah 172 orang sedangkan yang perempuan adalah 1.097 orang. Kompetensi bagi para peserta didik yang ditawarkan dari sekolah adalah akomodasi perhotelan, tata boga, tata busana dan tata kecantikan. Hasil survei yang telah dilakukan oleh Tim Pengabdian dari Universitas Slamet Riyadi Surakarta pada tanggal 20 Pebruari 2018 menunjukkan bahwa lulusan dari sekolah ini telah terserap dengan baik dan mendekati target maksimal di dunia industri. Untuk jurusan perhotelah, banyak alumnus yang telah mendapatkan pekerjaan di berbagai hotel ternama di Kota Surakarta antara lain Hotel Aziza, Sahid Kusuma, dan Aston. Untuk lulusan tata boga dan busana selain mendapat pekerjaan di industri kuliner dan konveksi ada yang justru membuka wirausaha sendiri di rumahnya. Lulusan tata kecantikan banyak yang bekerja di salon ataupun industri termasuk Larissa, Natasha dan usaha sendiri.

Dari lulusan yang berhasil mendapatkan pekerjaan tersebut sepertinya sekolah vokasi saat ini telah mendapatkan tempat di masyarakat. Hal ini tidak terlepas dari peran guru sebagai tenaga pengajar yang menjadi inspirator, fasilitator dan motivator bagi para siswanya. Untuk meningkatkan kemampuan guru agar mendapatkan lulusan yang diharapkan tersebut, guru tidak hanya mengandalkan pada ilmu yang telah diterimanya namun juga perlu dikembangkan. Sampai saat ini, masih banyak masyarakat yang menaruh kepercayaan dan harapan besar kepada guru sebagai aktor yang mampu menyebarkan virus positif dalam bentuk pengetahuan, pengalaman, dan ketrampilan kepada peserta didiknya. Kemampuannya dalam memberikan dan menularkan pengetahuan kepada generasi muda menjadikan gelar guru sangat 
dihormati. Guru yang masih aktif pada masa globalisasi sekarang ini memiliki beban dan tanggung jawab yang lebih besar dibanding pada masa sebelumnya. Dalam Pasal 10 Undang-Undang No. 14 Tahun 2005 mengenai Sertifikasi Guru dan Dosen dijelaskan bahwa seorang guru hendaknya memiliki kompetensi pada bidang pedagogik, kepribadian, sosial, dan profesional melalui pendidikan profesi.

Tuntutan adanya profesionalisme bagi para tenaga pendidik khususnya guru perempuan adalah kurangnya kemampuan dalam mengatasi permasalah peserta didik yang masih tergolong remaja. Remaja saat ini tidak sama dengan beberapa waktu lalu yang masih mudah menerima nasihat dari orang yang lebih tua termasuk para guru. Seiring dengan perkembangan teknologi komunikasi dan informasi membawa pengaruh yang sangat besar bagi peserta didik. Berdasarkan hasil wawancara dari Tim Pengabdian dengan seorang guru bidang studi kewirausahaan, Koes Wardiyanti 20 Pebruari 2018 menjelaskan bahwa masih ada guru perempuan yang kewalahan dalam mengatasi "kenakalan remaja” yang terkena pengaruh negatif dari alat komunikasi yakni gadget. Ketika mengikuti pembelajaran dalam kelas, tidak sedikit siswa yang secara diam-diam menggunakan gadget untuk bercermin dan berinteraksi dengan teman-temannya. Kebetulan jumlah siswa lebih banyak yang perempuan sehingga kecemasan akan penampilannya lebih banyak dan membutuhkan cermin.

Guru yang ada di SMK Negeri 4 Surakarta terutama yang perempuan masih ada yang mengalami kendala dalam memanfaatkan tekonologi untuk memperlancar proses pembelajaran di dalam kelas. Beberapa tenaga pengajar lebih merasa nyaman ketika proses pembelajaran menggunakan buku sebagai sumber materinya. Aktivitas semacam ini bagi peserta didik jika dilakukan hanya beberapa kali masih menerima namun jika dilaksanakan secara terus-menerus menimbulkan kebosanan. Buku teks untuk saat ini memang masih bisa digunakan sebagai sumber pembelajaran namun bukan sebagai yang utama. Guru perlu menyiasatinya dengan memanfaatkan sumber pembelajaran lain melalui internet.

Selain permasalahan tersebut, siswa remaja yang didominasi perempuan tersebut ketika diberi tugas belum dilaksanakan dengan baik. Salah satu penyebab kurangnya motivasi siswa dalam mengerjakan tugas dan memperhatikan pelajaran 
yang disampaikan guru disebabkan karena masih monotonnya metode yang diberikan, terlebih bagi guru yang hampir mendekati masa pensiun. Guru perempuan lebih banyak mengambil peran dalam pembelajaran kelas sehingga kurangnya kesempatan kepada siswa untuk berkreasi dan mengembangkan inovasinya, demikian penjelasan yang diberikan oleh Ratnawati seorang guru mata pelajaran Bahasa Inggris (21 Pebruari 2018). Dengan kondisi demikian, siswa menjadi enggan untuk mengikuti pembelajaran atau jika masih mengikuti secara terpaksa karena ajakan teman atau canggung dengan guru yang bersangkutan. Guru perempuan ada kalanya kurang memiliki kekuatan untuk menggertak siswa dibanding guru laki-laki. Artinya bahwa siswa terkadang lebih takut pada guru laki-laki dibandingkan guru perempuan.

Duman (2012) menjelaskan bahwa perempuan sebagai bagian dari masyarakat hendaknya memiliki peran yang sama dengan laki-laki. Dari pernyataan tersebut, Duman hendak menyampaikan sebuah pesan bahwa perempuan mestinya mendapatkan kesempatan dan penghargaan yang sama dengan laki-laki. Masyarakat terlebih dari negara-negara berkembang justru lebih sering menempatkan perempuan pada strata yang lebih rendah dibandingkan dengan laki-laki. Perempuan kurang mendapat kesempatan untuk mengimplementasikan potensi dan kemampuannya sendiri. Di sisi lain, masyarakat hendaknya juga diberikan edukasi dalam bentuk pemahaman sehingga tidak lagi atau setidaknya memberikan porsi yang sama antara perempuan dan laki-laki dalam berbagai aktivitas. Masyarakat sekaligus diharapkan juga memberikan kepercayaan kepada perempuan untuk berperan sebagaimana layaknya laki-laki sesuai dengan harkat dan martabatnya.

Untuk itu melalui pengabdian ini bertujuan untuk (1) meningkatkan pengetahuan bagi sebagian guru perempuan dari SMK Negeri 4 Surakarta akan pentingnya memanfaatkan internet secara bijaksana guna menunjang proses belajar mengajar di kelas; (2) memberikan pelatihan dan pendampingan kepada sebagian guru perempuan untuk meningkatkan kemampuan menulis karya ilmiah dalam bentuk publikasi; (3) memberikan motivasi kepada sebagian guru perempuan untuk mengedit artikel ilmiahnya ke dalam bentuk opini dan dikirim 
ke media massa online. Adapun target dari pengabdian ini adalah: (1) memberikan sosialisasi kepada para guru perempuan dalam memanfaatkan teknologi informasi dan komunikasi secara bijaksana guna memperlancar dan menunjang proses belajar mengajar; (2) memberikan sosialisasi kepada para guru perempuan akan pengertian dan manfaat dari artikel ilmiah sebagai bagian dari penelitian yang dipublikasikan untuk mendapat apresiasi dan tanggapan dari masyarakat pembaca; (3) memberikan pelatihan pembuatan karya ilmiah kepada para guru perempuan. Luaran dari pengabdian ini adalah: (1) pembuatan laporan hasil pengabdian; (2) pembuatan artikel untuk publikasi ilmiah yang dimasukkan ke dalam jurnal hasil pengabdian; (3) memasukkan artikel dalam bentuk opini ke media massa online.

\section{METODE PELAKSANAAN}

Dalam melaksanakan pengabdian kepada masyarakat ini, yang menjadi mitra adalah SMK Negeri 4 Surakarta khususnya guru-guru perempuannya. Dengan adanya permasalahan tersebut maka solusi yang ditawarkan menggunakan metode sebagai berikut: 1) memberikan edukasi dalam bentuk sosialisasi kepada para guru perempuan akan pentingnya memanfaatkan gadeget secara bijaksana guna menunjang kelancara proses belajar mengajar 2) Tim Pengabdian memberikan pelatihan dalam menyusun artikel ilmiah berdaarkan pada penelitian yang telah dibuat yakni Penelitian Tindakan Kelas atau PTK 3) Tim Pengabdian memberikan pelatihan editing karya ilmiahnya menjadi sebuah tulisan opini agar bisa diterima oleh media massa. 4) Tim Pengabdian mendampingi dan memotivasi kepada para guru perempuan agar rajin menyusun artikel ilmiah.

Dalam melaksanakan pengabdian kepada masyarakat ini, Tim Pengabdian memiliki kepakaran dalam pembuatan karya ilmiah yang dibantu oleh tenaga ahli dari ilmu pendidikan. Untuk yang pembuatan karya ilmiah, Tim Pengabdian memiliki latar belakang pendidikan Ilmu Hubungan Internasional dengan mata kuliah yang diampu adalah Metode Penelitian. Sementara dosen dengan latar belakang pendidikan Taknik Informatika diperbantukan untuk memberikan sosialisasi mengenai pemanfaatan teknologi komunikasi dan informasi (internet) 
secara bijaksana. Pembentukan dan pembagian tugas tersebut dimaksudkan untuk mempermudah pelaksanaan kegiatan pengabdian yang diawali dengan sosialisasi, pelatihan, pendampingan dan pemberian motivasi bagi para guru mulai dari penyusunan artikel ilmiah dan pengiriman karya tersebut ke media massa.

Kegiatan pengabdian kepada masyarakat ini bisa terlaksana setelah mendapatkan informasi dari beberapa guru perempuan dari SMK Negeri 4 Surakarta yang merasa kewalahan dalam menghadapi permasalahan di kelas. Permasalahan tersebut terkait dengan rendahnya motivasi siswa dalam menerima informasi dari guru, sikap yang kurang sopan selama pembelajaran dan kurangnya daya kreativitas para guru dan siswa selama proses pembelajaran. Berikut ini adalah langkah-langkah kegiatan yang dilakukan oleh Tim Pengabdian dalam memberikan sosialisasi, pelatihan dan pendampingan kepada para guru perempuan SMK Negeri 4 Surakarta.

\section{HASIL PELAKSANAAN KEGIATAN}

Pemberdayaan perempuan dalam pembangunan sangat diperlukan. Pemberdayaan perempuan tersebut dapat diwujudkan dalam berbagai bidang khususnya pendidikan. Pola asuh dan pendidikan bagi anak sebagai bekal masa depannya sangat ditentukan oleh peran seorang perempuan baik ibu maupun guru. Studi dari Islahi (2013) menunjukkan bahwa perempuan yang berperan sebagai guru memiliki korelasi positif terhadap perkembangan anak dan ini sangat dibutuhkan dalam pembangunan untuk meningkatkan human index. Guru perempuan diharapkan memiliki kemampuan untuk lebih supportif, ekspresif, lebih informal, supel dan terbukan kepada murid dibanding tenaga pengajar lakilaki.

Lebih lanjut, Jackie (2008) memberikan sebuah bukti adanya korelasi antara jumlah guru-guru perempuan dengan banyak sedikitnya murid untuk bersekolah. Gambaran yang diberikan oleh Jackie lebih difokuskan pada anakanak usia sekolah di sub-Sahara Afrika, Afghanistan, Pakistan, Bangladesh dan Nepal. Menurutnya semakin banyak guru yang berkelamin perempuan semakin 
tinggi tingkat kepercayaan orang tua untuk menyekolahkan anaknya. Kepercayaan yang tinggi kepada guru perempuan lebih didasarkan pada sifat atau watak yang dimilikinya seperti sabar, perhatian, dan memiliki perasaan seperti ibu dari siswa yang bersangkutan. Berdasarkan dua gagasan tersebut dapat ditarik benang merah bahwa guru perempuan jika diberi kepercayaan dapat mengembangkan potensi dan naluri ke"perempuannya atau keibuannya”. Naluri tersebut dibawa serta ketika berhadapan dengan para peserta didik.

Bidang gender dan pembangunan membutuhkan adanya pemahaman pada bidang sosial dan budaya. Upaya meningkatkan bidang sosial budaya salah satunya dilakukan melalui pendidikan formal. Kegiatan pengabdian kepada masyarakat dengan mitra guru-guru SMK N 4 Surakarta dilaksanakan pada tanggal 2-30 Juli 2018. Kegiatan tersebut diawali dengan memberikan sosialisasi kepada para guru perempuan. Sosialisasi tersebut dilaksanakan pada tanggal 2 Juli dengan tujuan untuk memberikan wawasan kepada para guru perempuan mengenal lebih lanjut tentang pentingnya pembuatan artikel ilmiah. Artikel ilmiah ini dibuat berdasarkan pada riset sebelumnya yang dikenal dengan Penelitian Tindakan Kelas (PTK). Pada umumnya riset PTK ini dilaksanakan untuk mengatasi atau menyelesaikan permasalahan yang dihadapi guru selama proses pembelajaran di kelas.

Kegiatan sosialisasi ini hanya dilaksanakan satu hari dengan waktu dari jam 08.00-13.00. Waktu tersebut cukup memadai dan efektif untuk memberikan wawasan mengenai artikel ilmiah yang bisa dipublikasikan secara cetak maupun online. Artikel ilmiah yang dipublikasikan tersebut sangat membantu bagi para guru yang telah menerima sertifikasi pendidik profesional. Dalam kegiatan sosialisasi ini diikuti oleh 36 guru dari latar belakang bidang pengajaran yang beragam. Acara sosialisasi dibuka oleh Kepala Sekolah yang diwakilkan oleh Wakil Kepala Sekolah bidang Kurikulum. Sambutan yang disampaikan oleh Wakil Kepala Sekolah pada dasarnya berisikan motivasi kepada para guru terutama yang telah menerima sertifikasi guru untuk lebih meningkatkan profesionalismenya terutama dengan aktif menulis. Dalam acara ini juga dihadiri oleh perwakilan dari Dinas Pendidikan Kota Surakarta. Sambutan dari Dinas 
Pendidikan pada dasarnya juga menandaskan kepada para guru untuk lebih aktif dan kreatif dengan mencari inovasi baru untuk membuat pembelajaran yang lebih menyenangkan.

Pembelajaran yang menyenangkan tersebut sangat diharapkan oleh para peserta didik saat ini mengingat godaan dan tantangan siswa dalam mengikuti proses belajar mengajar semakin banyak. Salah satunya adalah penggunaan gadget yang kurang bijaksana, pengaruh negatif dari teman atau lingkungan dan sebagainya yang semuanya bermuara pada lemahnya semangat untuk mengikuti pembelajaran dan kurangnya penghormatan atau kepatuhan terhadap orang yang lebih tua. Kesemuanya ini penting dalam proses pembangunan moral yang dialami Indonesia. Melalui pembangunan moral yang terus-menerus diberikan dan disebarluaskan dalam kerangka pendidikan formal diharapkan dapat meningkatkan budi pekerti atau karakter bagi generasi muda bangsa.

Pemberdayaan perempuan dalam pembangunan sangat diperlukan. Pemberdayaan perempuan tersebut dapat diwujudkan dalam berbagai bidang khususnya pendidikan. Pola asuh dan pendidikan bagi anak sebagai bekal masa depannya sangat ditentukan oleh peran seorang perempuan baik ibu maupun guru. Studi dari Islahi (2013) menunjukkan bahwa perempuan yang berperan sebagai guru memiliki korelasi positif terhadap perkembangan anak dan ini sangat dibutuhkan dalam pembangunan untuk meningkatkan human index. Guru perempuan diharapkan memiliki kemampuan untuk lebih supportif, ekspresif, lebih informal, supel dan terbukan kepada murid dibanding tenaga pengajar lakilaki.

Penelitian Tindakan Kelas yang telah dilakukan oleh guru-guru SMK N 4 Surakarta selama ini kurang maksimal. Tidak sedikit guru yang telah mengikuti pelatihan dan workshop untuk menyusun riset namun selain karena minat yang kurang juga tugas administratif dan beban mengajar yang tinggi menjadi alasan rendahnya penelitian. PTK selama ini yang telah dihasilkan oleh para guru perempuan tersebut berkaitan dengan strategi untuk meningkatkan semangat belajar karena metode pengajaran yang masih konvensional. Penelitian guru belum menyentuh pada pengaruh yang dihasilkan dari kemajuan teknologi 
komunikasi dan informasi terutama internet yang bisa diakses melalui gadget. Akibat globalisasi yang berkaitan dengan teknologi internet ini memiliki pengaruh yang besar terhadap siswa yang belum sempat mendapat pembekalan untuk memanfaatkannya secara bijaksana.

Berdasarkan pada pengamatan dan evaluasi yang dilakukan oleh Tim Pengabdian terhadap para peserta menunjukkan adanya motivasi tinggi untuk menyusun karya ilmiah yang dapat dipublikasikan. Riset yang telah dibuat dengan tujuan untuk mengatasi atau menyelesaikan permasalahan kelas hendaknya tidak hanya disimpan namun disebarluaskan melalui artikel ilmiah. Ratnawati, salah seorang peserta sekaligus sebagai guru Bahasa Inggris menyatakan menerima manfaat dari pelatihan penyusunan artikel ilmiah ini. Dengan artikel ilmiah yang dipublikasikan ke dalam jurnal dan media massa baik cetak maupun online dapat memberikan gambaran kepada para pembaca (sesama guru) akan karya kreatifitas dan inovasinya yang telah dibuat.

Setelah pelatihan yang diberikan kepada para guru perempuan terkait penyusunan artikel untuk publikasi ilmiah selesai, Tim Pengambdian tetap memberikan motivasi dan pendampingan lebih lanjut. Motivasi dan pendampingan ini diberikan kepada para guru agar menyusun kembali artikel ilmiah tersebut dan dikemas seperti tulisan opini untuk dikirimkan ke media massa cetak atau online. Media massa cetak yang dipilih dalam pelatihan ini adalah Majalah Pendidikan dan Keluarga GENTA. Pemilihan ini didasarkan pada sebuah alasan bahwa majalah ini langsung terkait dengan pendidikan formal mulai dari tingkat dasar hingga menengah atas. Untuk media massa online yang siap menerima karya guru pada wilayah Surakarta dan sekitarnya adalah poskita.co yang di dalamnya terdapat ruang pendidikan dalam bentuk opini atau kolom.

Berdasarkan pada evaluasi yang telah dilakukan oleh Tim Pengabdian dengan mitra yang dalam hal ini adalah SMK N 4 Surakarta terdapat beberapa catatan penting yakni: (1) para peserta sangat antusias terdapat program kegiatan pelatihan dan pendampingan ini karena terkesan lebih santai dan komunikatif antara pihak pelatih dan yang dilatih; (2) pelatihan ini sekaligus sebagai ajang bertukar informasi, wawasan dan pengalaman diantara para guru; (3) guru 
perempuan yang selama ini kurang kreatif, inovatif dan komunikatif menjadi lebih berani mencoba sesuatu yang baru; (4) beberapa guru merasa lebih diberdayakan dan diasah kemampuan dan potensinya; (5) beberapa peserta bahkan menjelaskan bahwa dengan mengikuti pelatihan tersebut memberikan kesempatan untuk berpartisipasi dalam proses pembangunan manusia yang berkelanjutan.

\section{KESIMPULAN}

Program kegiatan pengabdian kepada masyarakat yang dilaksanakan dengan mitra dari SMK N 4 Surakarta memberikan kontribusi yang positif. Kontribusi positif tersebut dialami oleh para guru perempuan baik yang telah menerima sertifikasi maupun yang belum. Bagi guru-guru muda, pelatihan ini memberikan pengalaman baru untuk termotivasi belajar membuat publikasi ilmiah sendiri. Bagi guru-guru yang telah menerima sertifikasi, pelatihan ini mendorongnya untuk lebih banyak melakukan penelitian tindakan kelas guna mengatasi permasalahan pembelajaran. Melalui penulisan artikel ilmiah yang dipublikasikan menjadi sebuah kesempatan bagi para guru perempuan untuk berperan dalam proses pembangunan manusia yang berkelanjutan.

\section{DAFTAR PUSTAKA}

Boateng, Oti, (2016). Ensuring The Central Role of Women in Development, International Journal of Gender and Women's Studies, Vol 4 (2).

Duman, Fatih, (2012). The Roots of Modern Feminism: Marry Wollstonecraft and the French Revolution, International Journal of Humanities and Social, Vol. 2, No.9 (hal:81), University of Turkey.

Islahi, Fatima dan Nasreen (2013). Who Make Affective Teachers: Men or Women an Indian Perspectives, Universal Journal of Educational Research 1(4), (hal:286), $\quad$ DOI: $\quad 10 . \quad$ 13189/ujer.2013.010402, https://files.eric.ed.gov/fulltext/EJ1053959.pdf.

Jackie, Kerk (2008). The Impact of Women Teacher toward Girl's Education, Bangkok: UNESCO Asia and Pasific Regional Bureau for Education (hal:2). 
Monkman, Karen, (2011). Framing, Gender, and Development, Research in Comparative and International Education, Vol. 6, No.1 (hal: 3). http://journals.sagepub.com/doi/pdf/10.2304/rcie.2011.6.1.1.

Rusniati, (2015). Pendidikan Nasional dan Tantangan Globalisasi: Kajian Kritis terhadap Pemikiran A. Malik Fajar, Jurnal Ilmiah Didaktika, Vol. 16. No. 1 (hal: 107). 